\title{
Extração de DNA genômico em tecidos sólidos de peixes teleósteos
}

\section{Extraction of genomic DNA from solid tissues of teleostei fish}

\author{
Nilton Garcia Marengoni ${ }^{1 *}$; Marcia Regina Fragoso Machado ${ }^{2}$; Eliane Gasparino ${ }^{3}$
}

\section{Resumo}

O objetivo desse trabalho foi extrair o DNA genômico de tecidos sólidos de tilápia do Nilo (Oreochromis niloticus), pacu (Piaractus mesopotamicus), piau (Leporinus sp.) e curimba (Prochilodus lineatus), utilizando os métodos Proteinase K (PK) e Brometo de Cetiltrimetilamônio (CTAB). O DNA extraído das amostras de fígado, rim, nadadeira caudal, coração, músculo e brânquias foi quantificado em espectrofotômetro para determinação da concentração e da pureza por meio da razão A260 $/ \mathrm{Am} 280_{\mathrm{nm}}$. Os dados foram estatisticamente analisados e não se observou efeito significativo para a interação entre espécies e tecidos em relação à pureza e concentração do DNA obtido a partir do CTAB, porém para PK houve interação em relação à concentração. Utilizando o método CTAB verificou-se que a concentração média de DNA no rim de curimba foi significativamente $(\mathrm{p}<0,05)$ inferior $(106,98 \mu \mathrm{g} / \mathrm{mL})$ à observada em pacu $(1727,90 \mu \mathrm{g} / \mathrm{mL})$, porém não diferiram das encontradas em piau $(497,20 \mu \mathrm{g} / \mathrm{mL})$ e tilápia $(234,50 \mu \mathrm{g} /$ $\mathrm{mL}$ ). Para o método PK, a concentração média de DNA utilizando o músculo de tilápia do Nilo apresentou o menor valor $(117,35 \mu \mathrm{g} / \mathrm{mL})$ em relação aos demais tecidos e espécies analisadas $(\mathrm{p}<0,05)$. A razão A260 $/{ }_{\mathrm{nm}} / \mathrm{A}^{28 n_{\mathrm{nm}}}$ variou de 1,7 a 2,0 e 1,6 a 2,1 para os métodos PK e CTAB, respectivamente. Conclui-se que a pureza do DNA foi alcançada nos diferentes tecidos estudados, demonstrando que o método PK pode ser utilizado para essas quatro espécies de peixes.

Palavras-chave: Leporinus sp, Oreochromis niloticus, Piaractus mesopotamicus, Prochilodus lineatus, DNA

\begin{abstract}
The object of this work was to extract the genomic DNA of solid tissue from Nile tilapia (Oreochromis niloticus), pacu (Piaractus mesopotamicus), piau (Leporinus sp.) and curimba (Prochilodus lineatus), using the methods Proteinase K (PK) and Cetyltrimethylammiun Bromide (CTAB). The DNA extracted from samples of liver, kidney, tail fin, heart, muscle and gills were quantified in spectrophotometer to determine the concentration and purity through the ratio A260 $/ \mathrm{nm} 280_{\mathrm{nm}}$. The data were statistically analyzed and there were no significant effect of interaction between species and tissues about the purity and concentration of the DNA obtained with CTAB, but for the PK there were interaction about the concentration. Using the CTAB method was verified that the mean quantity of DNA in the curimba kidney was significantly $(\mathrm{p}<0.05)$ lower $(106.98 \mu \mathrm{g} / \mathrm{mL})$ than the value observed in pacu, whereas, did not differ from the variables found in piau $(497.20 \mu \mathrm{g} / \mathrm{mL})$ and tilapia $(234.50 \mu \mathrm{g} / \mathrm{mL})$. For the PK method, the mean quantity of DNA using the muscle of Nile tilapia presented the lowest value $(117.35 \mu \mathrm{g} / \mathrm{mL})$ with reference to the other tissues and analyzed species $(\mathrm{P}<0.05)$. The ratio $\mathrm{A} 260_{\mathrm{nm}} / \mathrm{A} 280_{\mathrm{nm}}$ changed from 1.7 to 2.0 and 1.6 to 2.1 for the PK and CTAB methods, respectively. It may be concluded that the DNA purity was satisfactory for the different tissues on the four species of fish.
\end{abstract}

Key words: Leporinus sp, Oreochromis niloticus, Piaractus mesopotamicus, Prochilodus lineatus, DNA

1 Professor Adjunto do Centro de Ciências Agrárias da Universidade Estadual do Oeste do Paraná. Marechal Cândido Rondon, PR.

Brasil. Pesquisador do GESOMA. E-mail: marengoni@unioeste.br

2 Acadêmica do Curso de Zootecnia da Universidade Estadual do Oeste do Paraná.

3 Professora Adjunto do Departamento de Zootecnia da Universidade Estadual de Maringá.

* Autor para correspondência. 


\section{Introdução}

Situado numa região tropical, com um vasto território permeado por grandes bacias hidrográficas, o Brasil conta com uma numerosa e diversificada população de peixes, da qual constam espécies com características favoráveis à adaptação ao cultivo e manejo em programas de piscicultura. Em relação às características genéticas, o manejo zootécnico e o controle do processo reprodutivo possibilitam a realização de cruzamentos, criando condições para o direcionamento seguro de uma boa produção nos estoques de peixes (FORESTI, 2001; MELAMED et al., 2001; MOREIRA, 2001).

De acordo com Sollero et al. (2004), o DNA corresponde à matéria prima para qualquer conhecimento de genética. Estudos básicos sobre metodologias específicas que possam otimizar a extração de DNA de boa qualidade de uma amostra, para que as regiões desejadas sejam localizadas e amplificadas, são de grande importância para o desenvolvimento de pesquisas no campo da biologia molecular.

O isolamento do DNA é uma etapa importante na análise de estrutura e organização do genoma dos animais. Independente do tipo de estudo molecular, as preparações de DNA devem produzir amostras puras suficientes para não inibir os tratamentos enzimáticos ou causar interferências nos padrões de migração em gel de eletroforese (ROMANO; MIRANDA, 1999). Para isso são utilizados protocolos de extração de DNA que, apesar de apresentarem pequenas diferenças na dependência do material biológico que será utilizado, consistem de duas etapas principais. Na primeira etapa os reagentes mais comumente empregados para a obtenção de lise das membranas celulares são os detergentes, permitindo a liberação do DNA. Na segunda etapa, realiza-se um ou mais tratamentos enzimáticos ou químicos para purificar a preparação de contaminantes como RNA, proteínas e outras macromoléculas (BLOOM; FREYER; MICKLOS, 2002).
Assim como os reagentes, a boa qualidade do DNA é essencial para se obter bom resultado em experimentos (HOY, 1994), especialmente no uso da reação da polimerase em cadeia (PCR), nos quais os excessos de estruturas celulares e proteínas podem inibir o processo de amplificação (SAIKI, 1990).

A extração do DNA tem sido realizada em diferentes tecidos de animais como sangue, sêmen e pêlos de touros de diferentes raças zebuínas (COELHO et al., 2004), sangue de aves (CAMPOS et al., 2003), folículos pilosos da espécie caprina (MENDONÇA; ARAÚJO, 2003). Outros estudos ainda enfatizam a utilização desse método em tecidos de peixes do gênero Astyanax bimaculatus (PAIVA, 2001), nadadeira caudal, tecido muscular e sangue em tilápia do Nilo (POVH et al., 2003; CARREIRO et al., 2003) e tecido muscular em suínos (SOLLERO et al., 2004). Alguns métodos de extração do DNA genômico foram descritos em procariontes e eucariontes, utilizando amostra de tecidos específicos (SAMBROOK; FRITSCH; MANIATIS, 1989). Porém, são poucos os trabalhos que utilizam o DNA de tecidos sólidos em diferentes espécies de peixes, como brânquias, coração, fígado e rim.

De acordo com Valentim, Vargas e Moreira (2003), a quantificação do DNA pode ser realizada por meio da comparação entre a intensidade das bandas visualizadas no gel de agarose das amostras extraídas, com aquela observada nos padrões de DNA lambda, que apresentam as concentrações de 5, 10 e $20 \mathrm{ng} / \mathrm{mL}$. Porém alguns autores vêm utilizando a análise espectrofotométrica para quantificar e avaliar a pureza que é expressa pela razão das absorbâncias $\mathrm{A}_{260 \mathrm{~nm}} / \mathrm{A}_{280 \mathrm{~nm}}$, para leitura do DNA e proteína, respectivamente.

Considerando a rapidez e praticidade para obtenção de DNA genômico, idealizou-se este trabalho com objetivo de extrair o DNA a partir de diferentes materiais biológicos provenientes de quatro espécies de peixes teleósteos, utilizando os métodos da Proteinase $\mathrm{K}(\mathrm{PK})$ e Brometo de Cetiltrimetilamônio (CTAB) que foram avaliados comparativamente. 


\section{Material e Métodos}

Foram utilizados para esse trabalho peixes das seguintes espécies: tilápia do Nilo (Oreochromis niloticus) da linhagem Bouaké, pacu (Piaractus mesopotamicus), piau (Leporinus sp.) e curimba (Prochilodus lineatus). Esses peixes foram obtidos da Estação Experimental de Piscicultura da Universidade Estadual de Maringá (UEM/ CODAPAR), localizada no distrito de Floriano no Município de Maringá, PR, Brasil, com auxílio de rede de arrasto e tarrafas. Os peixes foram transportados para o laboratório e insensibilizados por exposição ao gelo, tendo $0,5 \mathrm{~cm}^{2}$ de cada um dos seus tecidos coletados (fígado, rim, músculo, nadadeira caudal, coração e brânquias), sendo posteriormente fracionados em sub-amostragens de $0,05 \mathrm{~g}$, para cada um dos métodos avaliados. As amostras dos tecidos foram preservadas em microtubos com etanol $70 \%$ e armazenadas à temperatura de $-20{ }^{\circ} \mathrm{C}$ para posterior extração de DNA.

No método utilizando Proteinase K (BARDAKCI; SKIBINSKI, 1994), adaptado por Povh et al. (2003), fragmentos de fígado, rim, músculo, coração, brânquias e nadadeira caudal foram colocados em microtubos com $550 \mathrm{~mL}$ de tampão de lise (50 mM Tris- $\mathrm{HCl}, \mathrm{pH} 8,0 ; 50 \mathrm{mM}$ ácido etileno diamino tetracético - EDTA; $100 \mathrm{mM}$ $\mathrm{NaCl} ; 1 \%$ dodecil sulfato de sódio - SDS) e $200 \mathrm{mg} /$ $\mathrm{mL}$ de Proteinase $\mathrm{K}$ (Invitrogen ${ }^{\mathrm{TM}}$ ) e em seguida incubados em banho-maria a $50{ }^{\circ} \mathrm{C}$ por uma noite. Posteriormente, o DNA foi purificado com duas extrações com fenol-Tris pH 8,0 e três de clorofórmio. Para a precipitação do DNA utilizou-se acetato de sódio (3 M) e etanol absoluto (gelado) nas proporções de $1 / 10$ e 2,5 vezes o volume, respectivamente, permanecendo incubado por $2 \mathrm{~h}$ a $-20{ }^{\circ} \mathrm{C}$. Em seguida, o DNA foi retirado com uma pipeta de Pasteur adaptada, lavado com $2 \mathrm{~mL}$ de etanol 70\%, e ressuspendido em $100 \mathrm{~mL}$ de tampão TE $(10 \mathrm{mM}$ Tris-HCl, pH 8,0; 1 mM EDTA) e incubado com 30 $\mathrm{mg} / \mathrm{mL}$ de RNAse A (Sigma $\left.{ }^{\circledR}\right)$. O DNA permaneceu por $1 \mathrm{~h}$ em banho-maria a $37^{\circ} \mathrm{C}$, sendo, em seguida, armazenado $\mathrm{a}-20^{\circ} \mathrm{C}$, para posterior quantificação.

No método Brometo de Cetiltrimetilamônio (CTAB), proposto por Boyce e Zwick (1989) e realizado com modificações, os fragmentos dos tecidos colocados em eppendorfs com $500 \mathrm{~mL}$ de CTAB (200 mL de solução de CTAB: 160 mL $\mathrm{H}_{2} \mathrm{O}$ milli-Q; 16,36 g NaCl; 400 mL b-mercaptoetanol; 20 mL 1 M Tris-HCl, pH 8,0; 8 mL 0,5 M Na EDTA, $\mathrm{pH} 8,0 ; 4$ g CTAB, Sigma $^{\circledR}$ ) que foram triturados com auxílio de pistilo. A mistura foi posteriormente incubada em banho-maria a $60^{\circ} \mathrm{C}$ durante $1 \mathrm{~h}$; sendo a suspensão homogeneizada com um vórtex em intervalos de $20 \mathrm{~min}$. Após esse período, o material foi centrifugado a $13600 \mathrm{~g} / 2 \mathrm{~min}$ e o sobrenadante transferido para tubos tipo eppendorfs contendo 500 $\mathrm{mL}$ de clorofórmio:álcool isoamílico $(24: 1 ; \mathrm{v} / \mathrm{v})$. A solução foi homogeneizada e, posteriormente, centrifugada a $13600 \mathrm{~g} / 15 \mathrm{~min}$ para precipitação das proteínas na interface entre o CTAB e o álcool isoamílico. O sobrenadante foi transferido para um terceiro tubo contendo $250 \mathrm{~mL}$ de isopropanol resfriado $\left(-20^{\circ} \mathrm{C}\right)$, homogeneizado e mantido por 30 min a $4{ }^{\circ} \mathrm{C}$. Posteriormente, o DNA foi precipitado por centrífuga a $13600 \mathrm{~g} / 30 \mathrm{~min}$ e o sedimento lavado com etanol $75 \%$ e $100 \%$ (v/v). Finalmente, o material foi secado à temperatura ambiente e depois ressuspendido em Tris-HCl-EDTA, pH 8,0 (filtrado e estéril) e estocado a $-20{ }^{\circ} \mathrm{C}$ para posterior quantificação.

O DNA foi quantificado em espectrofotômetro GeneQuant II RNA/DNA Calculator (Pharmacia Biotech), no comprimento de onda de $260 \mathrm{~nm}$. Esse valor de absorbância quando multiplicado por 50 (1 absorbância a $260 \mathrm{~nm}$ corresponde a $50 \mu \mathrm{g} / \mathrm{mL}$ de DNA de fita dupla) e pelo fator de diluição, fornece a concentração de DNA em $\mu \mathrm{g} / \mathrm{mL}$. A confirmação da pureza do DNA foi verificada pela razão das absorbâncias 260nm e 280nm para leitura do DNA e proteína, respectivamente (BARBOSA, 1998). A quantidade de DNA foi determinada utilizando a seguinte equação: 


$$
[\mathrm{DNA}]=50 \mu \mathrm{g} / \mathrm{mL} \times \mathrm{D} \times \mathrm{A}_{260}
$$

Onde:

[DNA] = concentração do DNA $(\mu \mathrm{g} / \mathrm{mL})$; $\mathrm{D}=$ fator de diluição;

$\mathrm{A}_{260}=$ leitura obtida no comprimento de onda de $260 \mathrm{~nm}$.

Os dados foram analisados utilizando o delineamento experimental inteiramente casualisado, tendo como fatores as amostras dos seis tecidos de quatro espécies de peixes, num esquema fatorial $6 \times 4$, com quatro repetições. Os dados da concentração do DNA transformados em logaritmo e da razão (sem transformação) foram submetidos às análises estatísticas e as médias comparadas pelo teste de Tukey a 5\% de probabilidade, utilizando-se o Sistema de Análises Estatísticas e Genéticas-SAEG (UNIVERSIDADE FEDERAL DE VIÇOSA, 1999).

As variáveis foram analisadas de acordo com o modelo estatístico:

$$
\mathrm{Y}_{\mathrm{ijk}}=\mu+\mathrm{A}_{\mathrm{i}}+\mathrm{B}_{\mathrm{j}}+(\mathrm{AB})_{\mathrm{ij}}+\mathrm{E}_{\mathrm{ijk}}
$$

Onde:

$\mathrm{Y}_{\mathrm{ijk}}=$ observação referente à i-ésima espécie, no jésimo tecido na k-ésima repetição;

$\mu=$ média geral;

$\mathrm{A}_{\mathrm{i}}=$ efeito da categoria espécie $\mathrm{i}(\mathrm{i}=1 \mathrm{a} 4)$;

$\mathrm{B}_{\mathrm{j}}=$ efeito da categoria tecido $\mathrm{j}(\mathrm{j}=1$ a 6$)$;

$(\mathrm{AB})_{\mathrm{ij}}=$ efeito da interação entre espécie e tecido; $\mathrm{E}_{\mathrm{ijk}}=$ erro experimental.

\section{Resultados e Discussão}

Por meio da leitura espectrofotométrica do DNA extraído utilizando os métodos Proteinase $\mathrm{K}$ e Brometo de Cetiltrimetilamônio foram observadas diferenças na concentração e pureza do DNA de acordo com a origem de cada tecido e espécie de peixe. No método PK, as razões médias obtidas no presente trabalho variaram de 1,7 a 1,9, estando dentro da faixa recomendada (BARBOSA, 1998; FERREIRA; GRATTAPAGLIA, 1998). Não se verificou efeito significativo para a interação entre espécies e tecidos em relação à razão, porém houve interação $(p<0,05)$ em relação à concentração. Para o método $\mathrm{CTAB}$, os resultados das razões médias variam de 1,7 a 1,8 e não houve efeito significativo para a interação entre espécies e tecidos em relação à pureza e concentração do DNA (Tabela 1).

A concentração média de DNA utilizando como tecido o músculo de tilápia do Nilo apresentou o menor $(p<0,05)$ valor $(117,35 \mu \mathrm{g} / \mathrm{mL})$ em relação aos demais tecidos e espécies analisados, revelando valores mais baixos em relação aos encontrados por Biase et al. (2002) para tecidos sólidos em suínos como fígado, rim e músculo. Não houve diferença significativa na concentração média de DNA para todos os tecidos de pacu, piau e curimba (Tabela 2). Coelho et al. (2004), extraindo DNA de sangue, sêmen e pêlos de touros de diferentes raças zebuínas, utilizando o método Proteinase K, também não encontraram diferenças significativas entre os valores médios da quantidade de DNA nos três tecidos utilizados. 
Tabela 1. Valores médios da concentração $(\mu \mathrm{g} / \mathrm{mL})$ e pureza do DNA (expresso pela razão $\left.\mathrm{A}_{260 \mathrm{~nm}} / \mathrm{A}_{280 \mathrm{~nm}}\right)$, extraído de diferentes tecidos sólidos de quatro espécies de peixes de acordo com os métodos Proteinase K (PK) e Brometo de Cetiltrimetilamônio (CTAB)

\begin{tabular}{|c|c|c|c|c|}
\hline \multirow[t]{2}{*}{ Variáveis } & \multicolumn{2}{|c|}{ Proteinase $\mathrm{K}$} & \multicolumn{2}{|c|}{ CTAB } \\
\hline & $\begin{array}{c}\text { Concentração } \\
(\mu \mathrm{g} / \mathrm{mL})\end{array}$ & $\begin{array}{c}\text { Razão } \\
\left(\mathrm{A}_{260 \mathrm{~nm}} / \mathrm{A}_{280 \mathrm{~nm}}\right)\end{array}$ & $\begin{array}{c}\text { Concentração } \\
(\mu \mathrm{g} / \mathrm{mL})\end{array}$ & $\begin{array}{c}\text { Razão } \\
\left(\mathrm{A}_{260 \mathrm{~nm}} / \mathrm{A}_{280 \mathrm{~nm}}\right)\end{array}$ \\
\hline \multicolumn{5}{|l|}{ Espécies } \\
\hline Tilápia do Nilo & 605,05 & 1,7 & 616,08 & 1,8 \\
\hline Pacu & 521,53 & 1,8 & 797,58 & 1,7 \\
\hline Piau & 544,46 & 1,8 & 412,80 & 1,7 \\
\hline Curimba & 532,30 & 1,8 & 276,06 & 1,8 \\
\hline \multicolumn{5}{|l|}{ Tecidos } \\
\hline Fígado & 794,87 & 1,8 & 727,52 & 1,7 \\
\hline Rim & 567,49 & 1,7 & 641,64 & 1,8 \\
\hline Coração & 542,42 & 1,7 & 276,75 & 1,7 \\
\hline Brânquias & 555,22 & 1,7 & 792,49 & 1,7 \\
\hline Nadadeira & 561,86 & 1,8 & 348,22 & 1,8 \\
\hline Músculo & 283,16 & 1,9 & 367,16 & 1,8 \\
\hline \multicolumn{5}{|l|}{ Teste de F } \\
\hline Espécie (E) & $0,14^{\text {n.s. }}$ & $3,86^{*}$ & $3,14^{*}$ & $0,58^{\text {n.s. }}$ \\
\hline Tecido $(\mathrm{T})$ & $6,97^{*}$ & $4,03^{*}$ & $1,16^{\text {n.s. }}$ & $1,50^{\text {n.s. }}$ \\
\hline Interação (ExT) & $1,81^{*}$ & $0,61^{\text {n.s. }}$ & $1,12^{\text {n.s. }}$ & $1,60^{\text {n.s. }}$ \\
\hline Coeficiente de Variação & 10,21 & 7,96 & 17,42 & 7,27 \\
\hline
\end{tabular}

*- significativo $(p<0,05)$; n.s. - não significativo $(p>0,05)$ pelo teste de Tukey.

Tabela 2. Valores médios da concentração de DNA $(\mu \mathrm{g} / \mathrm{mL})$, extraído de diferentes tecidos sólidos de quatro espécies de peixes, de acordo com os métodos Proteinase K (PK) e Brometo de Cetiltrimetilamônio (CTAB)

\begin{tabular}{|c|c|c|c|c|c|c|c|c|}
\hline \multirow[t]{3}{*}{ Tecidos } & \multicolumn{8}{|c|}{ Espécies } \\
\hline & \multicolumn{2}{|c|}{ Tilápia } & \multicolumn{2}{|c|}{ Pacu } & \multicolumn{2}{|c|}{ Piau } & \multicolumn{2}{|c|}{ Curimba } \\
\hline & PK & CTAB & PK & CTAB & $\overline{\mathrm{PK}}$ & CTAB & PK & CTAB \\
\hline Fígado & $971,37 \mathrm{Aa}$ & $1363,85 \mathrm{Aa}$ & $862,10 \mathrm{Aa}$ & $1057,40 \mathrm{Aa}$ & $816,30 \mathrm{Aa}$ & $177,95 \mathrm{Aa}$ & $529,70 \mathrm{Aa}$ & $310,90 \mathrm{Aa}$ \\
\hline Rim & $488,30 \mathrm{Aa}$ & $234,50 \mathrm{Aab}$ & $504,75 \mathrm{Aa}$ & $1727,90 \mathrm{Aa}$ & $724,37 \mathrm{Aa}$ & $497,20 \mathrm{Aab}$ & $552,55 \mathrm{Aa}$ & $106,98 \mathrm{Ab}$ \\
\hline Coração & $550,27 \mathrm{Aa}$ & $412,45 \mathrm{Aa}$ & $345,25 \mathrm{Aa}$ & $215,00 \mathrm{Aa}$ & $598,20 \mathrm{Aa}$ & $362,40 \mathrm{Aa}$ & $675,95 \mathrm{Aa}$ & $117,15 \mathrm{Aa}$ \\
\hline Brânquias & $629,25 \mathrm{Aa}$ & $1026,15 \mathrm{Aa}$ & $614,50 \mathrm{Aa}$ & $877,55 \mathrm{Aa}$ & $531,25 \mathrm{Aa}$ & $792,70 \mathrm{Aa}$ & $445,87 \mathrm{Aa}$ & $473,55 \mathrm{Aa}$ \\
\hline Nadadeira & $873,75 \mathrm{Aa}$ & $460,50 \mathrm{Aa}$ & $457,47 \mathrm{Aa}$ & $446,50 \mathrm{Aa}$ & $276,72 \mathrm{Aa}$ & $346,60 \mathrm{Aa}$ & $639,50 \mathrm{Aa}$ & $139,30 \mathrm{Aa}$ \\
\hline Músculo & $117,35 \mathrm{Bb}$ & $199,05 \mathrm{Aa}$ & $345,12 \mathrm{Aa}$ & $461,15 \mathrm{Aa}$ & $319,90 \mathrm{Aa}$ & $299,95 \mathrm{Aa}$ & $350,25 \mathrm{Aa}$ & $508,50 \mathrm{Aa}$ \\
\hline
\end{tabular}

Em cada coluna (letra maiúscula) e cada linha (letra minúscula), médias seguidas por mesma letra não diferem estatisticamente pelo teste de Tukey $(\mathrm{p}>0,05)$. 
$\mathrm{Na}$ Tabela 2, analisando os valores da concentração de DNA para diferentes tecidos e espécies, utilizando o método CTAB verifica-se que a concentração média de DNA no rim de curimba $(106,98 \mu \mathrm{g} / \mathrm{mL})$ foi inferior $(\mathrm{p}<0,05)$ à observada em pacu $(1727,90 \mu \mathrm{g} / \mathrm{mL})$, porém não diferindo das encontradas em piau $(497,20$ $\mu \mathrm{g} / \mathrm{mL}$ ) e tilápia $(234,50 \mu \mathrm{g} / \mathrm{mL})$. Sollero et al. (2004), extraindo DNA de tecido muscular de suínos, utilizando o método CTAB, também encontraram valores altos $(1938,9 \mu \mathrm{g} / \mathrm{mL})$ para a concentração de DNA, sendo considerado de boa quantidade. Não houve diferença significativa da concentração média de DNA para tilápia, pacu e piau.

Em relação à pureza do DNA expressa pela relação das absorbâncias $\mathrm{A}_{260 \mathrm{~nm}} / \mathrm{A}_{280 \mathrm{~nm}}$, observou-se que para o método $\mathrm{PK}$, os valores apresentados foram considerados satisfatórios. A razão das absorbâncias 260nm e 280nm variou de 1,7 a 2,0 para todas as amostras, indicando que não houve excesso de proteína o que poderia prejudicar a amplificação. Isso indica que as amostras são puras, pois segundo Barbosa (1998) e Ferreira e Grattapaglia (1998), a razão esperada como satisfatória é de 1,8 a 2,0, sendo aceitável 1,7 para todas as amostras. Os resultados da pureza do DNA extraído da nadadeira caudal de tilápia do Nilo estão de acordo com Povh et al. (2005). Utilizando o método CTAB, não foram alcançados índices de pureza satisfatórios para rim e coração de pacu e para coração de curimba $\left(\mathrm{A}_{260 \mathrm{~nm}} / \mathrm{A}_{280 \mathrm{~nm}}=\right.$ $1,6)$, indicando uma possível contaminação de proteínas, sendo que os valores encontrados obtiveram razões abaixo do preconizado. Para os demais tecidos a extração de DNA apresentou resultados considerados de boa qualidade (Tabela 3 ).

Tabela 3. Valores médios da pureza do DNA, expresso pela razão $A_{260 \mathrm{~nm}} / \mathrm{A}_{280 \mathrm{~nm}}$, extraído de diferentes tecidos sólidos de quatro espécies de peixes de acordo com os métodos Proteinase K (PK) e Brometo de Cetiltrimetilamônio (CTAB)

\begin{tabular}{|c|c|c|c|c|c|c|c|c|}
\hline \multirow[t]{3}{*}{ Tecidos } & \multicolumn{8}{|c|}{ Espécies } \\
\hline & \multicolumn{2}{|c|}{ Tilápia } & \multicolumn{2}{|c|}{ Pacu } & \multicolumn{2}{|c|}{ Piau } & \multicolumn{2}{|c|}{ Curimba } \\
\hline & PK & CTAB & PK & CTAB & PK & CTAB & PK & CTAB \\
\hline Fígado & 1,8 & 1,7 & 1,8 & 1,7 & 1,8 & 1,7 & 1,7 & 1,7 \\
\hline Rim & 1,7 & 1,9 & 1,8 & 1,6 & 1,8 & 1,8 & 1,7 & 1,7 \\
\hline Coração & 1,7 & 1,8 & 1,9 & 1,6 & 1,7 & 1,8 & 1,7 & 1,6 \\
\hline Brânquias & 1,7 & 1,7 & 1,8 & 1,7 & 1,7 & 1,7 & 1,7 & 1,7 \\
\hline Nadadeira & 1,8 & 1,8 & 1,9 & 1,9 & 1,8 & 1,8 & 1,8 & 1,7 \\
\hline Músculo & 1,7 & 1,7 & 2,0 & 1,8 & 1,9 & 1,7 & 1,9 & 2,1 \\
\hline
\end{tabular}

Experimentos complementares devem ser realizados, utilizando esses tecidos, modificando e/ ou adaptando os métodos, pois tudo indica que as grandes variações também encontradas nos valores da concentração do DNA (Tabela 2) não sejam devido às espécies de peixes, mas provavelmente às falhas da extração. A contaminação por DNAse ou quebra mecânica durante a extração com clorofórmio e a contaminação por RNA são, entre outros, os problemas comumente encontrados durante o isolamento de DNA, utilizando o método CTAB (ROMANO; MIRANDA, 1999). Além disso, os métodos utilizando CTAB são amplamente adotados para a extração de DNA de plantas, fungos e artrópodes e, mesmo pequenas modificações nas concentrações dos reagentes poderiam afetar o resultado final das extrações (WALDSCHMIDT et al., 1997).

Vários procedimentos de extração de DNA têm sido descritos na literatura, observando-se que métodos padrões são utilizados com algumas modificações, visando solucionar os problemas específicos da espécie em estudo. Deve-se lembrar ainda que a forma de coleta e a conservação do tecido são consideradas de grande importância para a obtenção do DNA em concentração e qualidade adequadas (SOLLERO et al., 2004). A pureza do DNA é afetada significativamente pela condição do 
tecido anteriormente a extração e por esse motivo, recomenda-se utilizar o material mais fresco possível (FERREIRA; GRATTAPAGLIA, 1998). Na atual descrição, apesar das amostras terem sido coletadas, mantidas em etanol $70 \%$ e armazenadas à temperatura de $-20{ }^{\circ} \mathrm{C}$, por uma semana, garantiu dessa forma a qualidade dos tecidos indicada pelos valores da razão entre 1,7 a 2,0 utilizando o protocolo PK (Tabela 3).

Nesse estudo observou-se que é possível a utilização dos tecidos avaliados para a extração do DNA para as quatro espécies de peixes, utilizando os dois métodos de extração, apontando as vantagens e desvantagens de cada uma deles quanto à concentração e pureza do material genético obtido. Utilizando o método PK a extração foi eficaz, tanto para a pureza quanto para a quantidade do DNA, para todos os tecidos e espécies. Somente o rim e coração não forneceram bons resultados da extração com o método CTAB. Além desse fato, esses métodos mostraram-se satisfatórios quanto à facilidade de uso, baixo custo e rapidez na extração de DNA, quando comparados aos métodos que tornam a extração a partir de material congelado ineficientes. Recomenda-se ainda a utilização de músculo e principalmente nadadeira, pois com a utilização desses tecidos é possível a colheita de amostras sem a necessidade de abate dos peixes, que é o requisito de grande importância para as avaliações genéticas.

Considerando que a extração do DNA é uma das primeiras etapas para o monitoramento genético de populações, faz-se necessário obter uma quantidade suficiente de DNA de boa qualidade, para que as regiões desejadas sejam localizadas e amplificadas por meio de técnicas de biologia molecular. Nos últimos anos, a principal preocupação das pesquisas e trabalhos sobre genética e melhoramento de peixes no Brasil está sendo orientada para a caracterização dos bancos genéticos em populações nativas, estimando a variabilidade e divergência genética dentro e entre populações de peixes (LOPES et al., 2002). Nesse estudo, para melhor compreender a estrutura de populações de reprodutores de tilápia do Nilo, pacu, piau e curimba, primeiramente avaliouse a extração do DNA utilizando dois métodos que posteriormente será empregado na avaliação da divergência genética utilizando os marcadores moleculares.

\section{Referências}

BARBOSA, M. M. Quantificação e controle da qualidade do DNA genômico. In: MILACH, S. C. K. (Ed.). Marcadores moleculares em plantas. Porto Alegre: Sandra Milach, 1998.p.99-106

BARDAKCI, F.; SKIBINSKI, D. O. F. Application of the RAPD technique in tilapia fish: species and subspecies identification. Heredity, Edinburgh, v.73, n.2, p.117-123, 1994.

BIASE, F. H.; FRANCO, M. M.; GOULART, L. R.; ANTUNES, R. C. Protocol for extraction of genomic DNA from swine solid tissues. Genetics and Molecular Biology, Ribeirão Preto, v.25, n.3, p.313-315, 2002.

BLOOM, M. V.; FREYER, G. A.; MICKLOS, D. A. Laboratory DNA Science: an introduction to recombinant DNA techniques and methods of genome analysis. California: The Benjamin/Cummings Publishing Company 2002.

BOYCE, T. M.;ZWICK, M. E. Mitochondrial DNA in bark weevils: size, structure, and heteroplasmy. Genetics, Austin, v.12, n.3, p.825-836, 1989.

CAMPOS, R. L. R; AMBO, M.; NONES, K.; RUY, D. C.; BARON, E.; DEDUR, M. C.; COUTINHO, L. L. Otimização e comparação de protocolos para extração de DNA de sangue de aves. In: CONGRESSO BRASILEIRO DE GENÉTICA, 49., 2003. Águas de Lindóia. Anais...Águas de Lindóia: SBG, 2003. p.282.

CARREIRO, C. R. P.; MESQUITA, P. E. C.; TEIXEIRA, E. G.; VIEIRA, C. M. T.; LIMA, A. D. F.; FURTADO-NETO, M. A. A. Isolamento de DNA genômico de Tilápia (Oreochromis niloticus) var. Chitralada, como base para monitoramento genético. In: CONGRESSO BRASILEIRO DE ENGENHARIA DE PESCA, 13., 2003. Porto Seguro. Anais... Porto Seguro: FAEP-BR, 2003. v.1.p.322.

COELHO, E. G. A.; OLIVEIRA, D. A. A.; TEIXEIRA, C. S.; SAMPAIO, I. B. M.; RODRIGUES, S. G.; ALVES, C. Comparação entre métodos de estocagem de DNA extraído de amostras de sangue, sêmen e pêlos e entre técnicas de extração. Arquivo Brasileiro de Medicina Veterinária e Zootecnia, Belo Horizonte, v.56, n.1, p.111-115, 2004. 
FERREIRA, M. E.; GRATTAPAGLIA, D. Introdução ao uso de marcadores moleculares em análise genética. 3 ed. Brasília: EMBRAPA, 1998.

FORESTI, F. Melhoramento genético na piscicultura. Revista Brasileira de Agropecuária, São Paulo, v.1, n.12, p.23-25, 2001.

HOY, M. A. DNA amplification by the Polymerase Chain Reaction: molecular biology made accessible. In: Insect molecular genetics: an introduction principles and applications. San Diego: Academic Press, 1994. p.203-244.

LOPES, R.; LOPES, M. T. G.; FIGUEIRA, A. V. O.; CAMARGO, L. E. A.; FUNGARO, M. H. P.; CARNEIRO, M. S.; VIEIRA, M. L. C. Marcadores moleculares dominantes (RAPD e AFLP): aspectos técnicos e interpretação genética. Biotecnologia Ciência e Desenvolvimento, Brasília, v.5, n.29, p.56-60, 2002.

MELAMED, P.; GONG, Z.; FLETCHER, G.; HEW, C. L. The potential impact of modern biotechnology on fish aquaculture. Aquaculture, Amsterdam, v.2, n.4, p.255-269, 2001.

MENDONÇA, P. T.; ARAÚJO, M. A. Técnica de extração de DNA de folículos pilosos em caprinos. In: SIMPÓSIO DE INICIAÇÃO CIENTÍFICA, 13., 2003, Viçosa. Anais... Viçosa: UFV, 2003. CD-ROM.

MOREIRA, H. L. M. Genética e melhoramento de peixes. In: MOREIRA, H. L. M.; VARGAS, L.; RIBEIRO R.; ZIMMERMANN, S. Fundamentos da moderna aqüicultura. Canoas: ULBRA, 2001.p.135-147.

PAIVA, S. R. Influência de obstáculos naturais na divergência de populações de Astyanax bimaculatus na bacia do rio Doce-MG. 2001. Dissertação (Mestrado em Genética e Melhoramento) - Universidade Federal de Viçosa, Viçosa.

POVH, J. A.; BLANCK, D. V.; PETRONILO, V.; MOREIRA, H. L. M.; RIBEIRO, R. P.; VARGAS, L., CAVALLIERI, R. F. D.; BENITES, C. Comparação de duas linhagens de tilápia do Nilo (Oreochromis niloticus). In: CONGRESSO INTERNACIONAL DE ZOOTECNIA, 5., CONGRESSO NACIONAL DE ZOOTECNIA, 12., 2003, Uberaba. Anais... Uberaba: ABCZ-ABZ, 2003.p.417-421.
POVH, J. A.; MOREIRA, H. L. M.; RIBEIRO, R. P.; PRIOLI, A. J.; VARGAS, L.; BLANCK, D. V.; GASPARINO, E.; STREIT JR., D. P. Estimativa da variabilidade genética em linhagens de tilápia do Nilo (Oreochromis niloticus) com a técnica de RAPD. Acta Scientiarum, Maringá, v.27, n.1, p.1-10, 2005.

ROMANO, E.; MIRANDA, A. C. B. Extração de DNA de plantas: soluções para problemas comumente encontrados. Biotecnologia Ciência e Desenvolvimento, Brasília, v.2, n.9, p.40-43, 1999.

SAIKI, R. K. Amplification of genomic DNA. In: IINNIS, M. A.; GELFAND, D. H.; SNINSKI, J. J.; WHITE, T. J(Ed.). PCR protocols: a guide to methods and applications. San Diego: Academic Press, 1990. p.13-20

SAMBROOK, J.; FRITSCH, E. F.; MANIATIS, T. Molecular cloning: a laboratory manual. 2 ed. New York: Cold Spring Harbor Laboratory Press, 1989.

SOLLERO, B. P.; FARIA, D. A.; PAIVA, S. R.; GUIMARÃES, S. E. F.; LOPES, P. S.; PAIXÃO, D. M. Método rápido de extração de DNA utilizando CTAB em tecidos musculares de suínos. In: CONGRESSO INTERNACIONAL DE ZOOTECNIA, 6., CONGRESSO NACIONAL DE ZOOTECNIA, 13., 2004. Brasília. Anais... Brasília: SBZ, 2004. CD-ROM.

UNIVERSIDADE FEDERAL DE VIÇOSA. SAEG : sistema para análises estatísticas e genéticas: Manual do usuário. Viçosa, 1999.

VALENTIM, M.; VARGAS, L.; MOREIRA, H. L. M. Comparação de protocolos para extração do DNA de Lernaea sp. (Copepoda: Cyclopoida). Acta Scientiarum, Maringá, v.25, n.2, p.219-222, 2003.

WALDSCHMIDT, A. M.; SALOMÃO, T. M. F.; BARROS, E. G.; CAMPOS, L. A. O. Extraction of genomic DNA from Melipona quadrifasciata (Hymenoptera: Apidae, Meliponinae). Brazilian Journal of Genetics, Ribeirão Preto, v.20, n.3, p.421-423, 1997. 